\title{
A New Natural Interpretation of the Empty Tomb
}

\author{
Leonard Irwin Eisenberg ${ }^{1}$
}

Received: 22 May 2015/ Accepted: 14 December 2015/Published online: 19 January 2016

(C) The Author(s) 2016. This article is published with open access at Springerlink.com

\begin{abstract}
Clues in the Gospels, evidence from Jewish historian Josephus, belief in the transmigration of souls, and well-documented examples of erroneous declarations of death, combine to support a natural explanation for the Easter story: (1) Jesus survives his short stay on the cross, and (2) is discovered to be barely alive by the few followers who retrieve him. (3) Fearful because they have illegally retrieved a condemned man, they carry out a decoy burial in a tomb. (4) Jesus expires soon after, and is buried quietly in an anonymous grave, but (5) rumor of his survival reaches his followers, as well as the Romans, who (6) open the tomb and find it empty, except for burial linen used in the decoy. (7) To sooth their grief the disciples seize on the rumor of Jesus' survival and encourage each other to hear the voice and see the image of their master in others. Although the probability of the scenario proposed herein is low, it is surely far larger than the supernatural one. It also is arguably more likely than other non-supernatural hypotheses. It does not require Jesus to survive his crucifixion and meet his followers, or, if Jesus died, to have his body stolen, or be removed from the tomb after the Sabbath and reburied in a lower class graveyard. One only need propose that Jesus was still alive (barely) when taken down from the cross and envision how events most likely would unfold from there.
\end{abstract}

Keywords Resurrection - Empty tomb · Jesus · Crucifixion · Christianity · Christian apologetics

Leonard Irwin Eisenberg

evogeneao@gmail.com

1223 Granite Street, Ashland, OR 97520, USA 


\section{Introduction}

The purpose of this paper is not to determine the historicity of Jesus, or examine the validity of apologist historical claims. Instead this paper accepts the key evidence for the resurrection (the empty tomb and appearance stories) and proposes that they are most plausibly interpreted as the result of a confluence of natural events that begins with Jesus still (barely) alive when retrieved from the cross. Evidence for this interpretation is found in details of the Gospel stories of Jesus' crucifixion, the empty tomb, and appearances to disciples. These details are significant because they do not seem to be items that would have been added later to make the Gospels more inspiring, heroic, or divine. Christian apologists point to these details as evidence for the overall historical accuracy of the Gospels, and thus the truth of the resurrection (Craig 1994, 2010). However, these same Gospel details, along with evidence from Jewish historian Josephus, and modern medical records that document numerous erroneous declarations of death, point to a plausible chain of natural events that became embellished into the supernatural story upon which Christianity rests.

\section{Apologist argument for the resurrection}

William Lane Craig in Reasonable Faith (1994) and follow-up publication (On Guard: Defending your Faith with Reason and Precision 2010) uses four evidential claims to support a supernatural interpretation of events at the end of Jesus' life. The first is the empty tomb, second is reports of Jesus' post-crucifixion appearances, third is the disciple's devotion, and the fourth is the short time between events at the end of Jesus' life and their commitment to print. He also points to the central place of women in parts of the Gospels, despite their low status, as evidence for the historical truth of the Gospels. The third point can be safely left aside. Both Muslims and Mormons, among others, used followers' devotion, despite persecution, both real and claimed, to spread and prosper. In fact, early Christians were not as persecuted as later church stories would have it (Moss 2013). The apologist claim about women is equally weak. First century women were prominent in other religions, including Judaism, and Roman and Jewish law clearly permitted their testimony. It was only unseemly for women to be in public where normally only men appeared, and in some cases they did anyway (Kraemer 2004, pp. 32, 241-282).

The fourth point suggests that the relatively brief twenty to thirty years between the death of Jesus and Paul's reference to the resurrection and appearances in 1 Cor. 15:3-7 (Price 2003) was not long enough to allow supernatural embellishment. But there is ample evidence that legends can grow within short time frames. The example of Alexander the Great is particularly revealing. Alexander was undoubtedly a person of considerable public interest, and despite voluminous contemporary recording of his life and deeds, he still attracted supernatural embellishments during his own lifetime. Jesus on the other hand was not a person of 
significant public interest, (the only record we have of his life comes late and from his disciples; there are no contemporary accounts), and therefore constraints on embellishments to the historical record about Jesus would have been far less (Komarnitsky 2013). Habermas and Licona (2004) also claim the conversion of the skeptic James and the persecutor Paul as evidence of the supernatural resurrection of Jesus, but given the mobility of religious belief (Kirsch 2004; http://religions. pewforum.org/reports) such claims cannot be taken seriously. Therefore, it is the claim of an empty tomb, and reported post-crucifixion appearances to Jesus' followers that are the crux of the apologist argument.

\section{Crucifixion and an empty tomb}

Apologists believe that Jesus truly died on the cross, and claim he could not have fainted or faked his death (Schonfield 1965; Price 2011), or survived crucifixion (Strobel 1998, pp. 265-271). But some scholars have suggested Jesus survived, and point out that some early religious factions believed he did (Thiering 1992; Price 2011). Clues from the New Testament also suggest a survival story was present when the Gospels were written (Price 2003, pp. 326-330). There are several reported instances of survival from crucifixion (Derrett and Duncan 2005, p. 394, 405, note 6).

If Jesus (barely) survived the cross, the empty tomb becomes a plausible consequence. There is no direct evidence that Jesus survived his crucifixion, but Flavius Josephus, a Jewish historian of the first century, describes how he rescued three crucified acquaintances while he was performing military duties for Rome, and that all three were alive when retrieved. Because crucifixion killed over several days by dehydration (Price 2003, p. 326), or asphyxiation (Crossan and Reed 2001, p. 246), or hypovolemic shock (Zugibe 1984), a critical question becomes; how long were Josephus' survivors on the cross, and how does that compare to the time Jesus was on the cross?

The following passage is from The Life of Flavius Josephus, from the end of chapter 75. Elsewhere in the extensive writings of Josephus (1900) there is at least one obvious later interpolation, but there is no reason to suspect the following passage is anything other than original text (Mason, Steven N., University of Aberdeen, and Patterson, Stephen, Willamette University, personal communications, 2011). The setting for this incident is the Jewish revolt from Rome (66-73 $\mathrm{CE}$ ), hence the large protective escort. It occurred in fall $70 \mathrm{CE}$ after the Romans captured Jerusalem, and before Titus went on a triumphal tour of the area. Alternatively, it may have occurred in spring $71 \mathrm{CE}$ when Titus stopped in Jerusalem on his way back to Rome, with Josephus.

And when I was sent by Titus Caesar with Cerealius, and a thousand horsemen, to a certain village called Thecoa, in order to know whether it were a place fit for a camp, as I came back, I saw many captives crucified, and remembered three of them as my former acquaintance. I was very sorry at this in my mind, and went with tears in my eyes to Titus, and told him of them; so 
he immediately commanded them to be taken down, and to have the greatest care taken of them, in order to their recovery; yet two of them died under the physician's hands, while the third recovered.

Thecoa was about six miles south of Bethlehem, which in turn was about six miles south of Jerusalem (O'Grady, 2012, p. 135; www.bible-history.com/ geography/ancient-israel/thecoa.html). We can reasonably assume that Josephus departed, and gathered his escort from, the neighborhood of Jerusalem (Josephus 1981, The Jewish War, p. 12). So about 12 miles for Josephus to travel one way to visit the village, examine its utility as a site for a military camp, then return 12 miles to Jerusalem. On horseback, with a large escort, on guard against rebel attacks, this expedition would likely have occupied a full day. They probably left soon after daybreak, so as to be able to get back before dark and still have enough time to reconnoiter. They likely would have used the same road to leave and return to Jerusalem. Josephus sees the men crucified on the way back, so they must have been crucified sometime after Josephus left Jerusalem. Josephus probably returned to Jerusalem in the late afternoon, before dark. More time is taken as Josephus must find Titus and beg for the men's lives, and for his order to spare them carried out. All this suggests that the three men endured crucifixion perhaps two to three hours, or as many as six to eight hours. Despite this, all three were alive, albeit barely, when retrieved from the cross.

Jesus' crucifixion is reported to have started either at the third hour after dawn (Mark 15:25), or around the sixth hour, or about noon (John 19:14-16; Matthew 27:45). At the ninth hour, or about 3 pm Jesus appears to die (Matthew 27:50). He seems to have stayed on the cross another hour or two. "When the even was come, there came a rich man of Arimathea, named Joseph, who also himself was Jesus' disciple: He went to Pilate and begged the body of Jesus." (Matthew 27:57-58). All this suggests that Jesus endured crucifixion between 4 and $8 \mathrm{~h}$. The style of crucifixion is suggested by the minimum time of Jesus' reported survival. Experiments on students, and evidence from Nazi death camps show that if a victim is affixed to a cross with arms stretched out to the side, and the lower body supported somehow, either by nailing the feet, or providing a small seat, up to a few days of survival are possible. If the body is unsupported and hanging from arms extended over the head, the victim dies within an hour. (www.mercaba.org/ FICHAS/upsa/crucifixion.htm).

When Joseph of Arimathea (probably an embellished figure, Price 2003, pp 326-327; Parsons 2005, p. 446), begs Pilate for Jesus' body, Pilate is surprised that he is already dead, and asks a centurion to confirm the death (Mark 15:43-45). This small detail is significant, in that it would not likely have been a later insertion, because it would cast some doubt on the claim of Jesus' death on the cross. It also is significant that it only appears in Mark, the first Gospel to be written (Smith 1978, p. 11; Aslan 2013, Introduction p. xxvi). The other synoptic Gospels, Mathew and Luke, which rely on Mark for much of their material, do not include it. Perhaps this detail was omitted because it did cast some doubt.

Another pertinent reference from Josephus describes how "... the Jews pay so much regard to obsequies that even those found guilty and crucified are taken down 
and buried before sunset" (Josephus 1981, The Jewish War, p. 260). This reasonably explains why disciples wished to retrieve Jesus soon after his apparent death, and why Pilate allowed Jesus to be removed from the cross, despite his suspicions. Before the first Jewish war, Jewish law was for the most part respected by the Romans (Carrier 2005a, pp. 373-375; Wedderburn 1999, p. 61). Crucifixion was a punishment used on peasants, slaves, and rebels, rarely on higher classes (Crossan and Reed 2001, p. 245, Hengel 1977, p. 34, pp. 46-63, 87-88). Pilate may not have paid much attention to the case of a low class messianic nuisance, being assured he was dead.

It was unusual for a body to be removed from the cross immediately after death. The typical Roman procedure was to let the corpse rot and be torn by animals (Crossan and Reed 2001, pp. 246-247; Hengel 1977, pp. 46-47; Lowder 2005, pp. 263-264; Parsons 2005, p. 445). But the Gospel story of Pilate allowing the body of Jesus to be removed is not without independent support. In 1968 the remains of a crucified man from the first century were found in a cave northeast of Jerusalem, with a nail still embedded in the heel. The circumstances of this find suggest the man's body was taken down soon after death because of the wealth and influence of his family (Crossan and Reed 2001, pp. 3-4, 246-247; Lowder 2005, p. 264). The discovery of this man's remains, and the reported timing of Jesus' crucifixion and involvement of the high-status Joseph figure, make the story of Pilate's early release of the body plausible (Lowder 2005, pp. 265-266).

Apologists reply to the Markan passage about Jesus' short time on the cross by pointing to the scourging of Jesus prior to his crucifixion (Mark 15:15, Mathew 27:26, John 19:1-3) as a reason for his quick death (Craig 1994, 2010). However, if Jesus was scourged, it was because scourging of persons to be crucified by Romans was common practice (Hengel 1977, p. 28-32; Aslan 2013, p. 158). It is likely that Jesus was treated no differently than other troublemakers the Romans crucified. Thus it seems reasonable to assume that Josephus' acquaintances also were scourged prior to crucifixion. And they were alive when taken down.

Pilate made his decision to release Jesus by trusting the centurion's confirmation. There is no evidence to suggest the centurion was lying, or bribed. The simplest explanation is that the centurion (or the soldier he sent to check for him) thought Jesus was dead. Apologists claim Roman soldiers could not have made a mistaken determination of death (Strobel 1998, pp. 265-271). But there are numerous welldocumented declarations of death by medical professionals that turned out to be false (Wilkins 1990; Davies 1998; Bondeson 2001).

False pronouncement of death by medical professionals, from the 1600's to the present day involve drowning, hanging, disease, sudden collapse, and many other circumstances (Wilkins 1990; Davies 1998; Bondeson 2001). A May 28, 2004 example reported by the Associated Press concerned a young Idaho boy who was declared dead by emergency personnel after 30 min of submersion. But when a nurse was preparing him for the funeral home, it became evident he was still alive. Another incident occurred in March 1988, when a man collapsed at home and was pronounced dead by not one, but two doctors. Fortunately the undertaker wasn't convinced, and the man recovered in hospital (Davies 1998, p. 64). 
Death by hanging would seem closest to that by crucifixion because, if the neck doesn't snap on the fall, a circumstance common in older executions, death occurs by asphyxiation, and there are many reports of false declarations of death by hanging (Davies 1998, p. 87-104). A well-documented case concerns a woman who hanged herself and appeared dead to the doctor who examined her: "She was pulseless at the wrist and temples. There was no beat of the heart recognizable by stethoscope. There was absolute cessation of all natural respiratory efforts, complete unconsciousness, total abolition of reflex action and motion, and galvanism with the ordinary magneto-electric machine failed to induce muscular contractions. The urine and feces had been passed involuntarily during or immediately subsequent to the act of suspension." The lack of reflexes extended to no reaction of the pupils to light exposure, and no reaction of the eyelids when the eyeball was touched. The failure of pupils to react to light is generally regarded as a reliable sign of death. But the woman was not dead, and later efforts to revive her were successful (Davies, 1998, pp. 102-104). In October 2013, a man hanged in Iran and declared dead by a doctor was found later in the morgue to be alive (New York Times, Oct. 22, 2013). In February 2014 a hospice nurse and a county coroner declared Walter Williams dead, but being prepared for embalming, he was found by mortuary workers still to be alive (http://www.bbc.com/news/world-us-canada-26388426).

These are but a few of many well-documented examples of mistaken declarations of death. Given the frequency of premature death declared by non-professionals, as well as professionals, one can reasonably propose that a first century Roman soldier, as well as Jesus' disciples, could have mistakenly assumed Jesus was dead.

Joseph of Arimathea thought Jesus was dead because he would not have dared ask for the body otherwise. If one assumes that Jesus was not dead, then soon after retrieving him Joseph would have realized that Jesus was still (barely) alive. It may have happened as they took him down, or perhaps as they were preparing him for burial. Joseph instantly would have been seized by a great fear and a great hope. Hope that this charismatic man would survive, and fear that the Romans would discover he had illegally rescued a condemned man. Joseph would have recognized he had only one chance to preserve his own life and that of Jesus. Joseph would have made outward preparations as if for a burial, even as he would have been trying to revive Jesus. Joseph would have continued the ruse by having his slaves go to an available tomb, carrying a corpse-shaped bundle of burial cloth, place it inside, and then seal the tomb. The time pressure imposed by Jewish law to bury a condemned man before sundown makes the reported use of a tomb plausible (Carrier 2005a, pp. 383-385). Rock-hewn tombs were expensive (Kirby 2005, p. 244), and although not the usual practice for the condemned, there is evidence dishonorable burial included tomb burial in first-century Palestine (Lowder 2005, pp. 266-267). If a few of Jesus' followers were around to witness the decoy burial (Mark 15:47, Matthew 27:61, Luke 23:55), the possible presence of Roman soldiers, and perhaps some pagans representing the interest of the Jewish hierarchy, would have kept them at a distance. Few others were likely to be present. Most of the Jewish population would have been home preparing for the Sabbath.

Another small detail in the Gospels can be seen to support this scenario. Luke 24:12 and John 20:5-8 speak of disciples seeing burial linens in the opened tomb. 
Because this story does not appear in Mark or Matthew, it could well be just an embellishment to the empty tomb story (Carrier 2005b, p. 353). Apologists use the reports of burial linens as evidence for the resurrection (Craig 1994, 2010; Strobel 1998), claiming that no other explanation but the supernatural one is possible. Far from it! If burial linens were indeed found in an empty tomb, they were more likely to have been placed there during a decoy burial.

Jesus may have survived for a short time after his crucifixion, but probably he didn't last long. Joseph of Aramithea would then have had only one choice, to bury Jesus, not in a tomb, but somewhere quiet and inconspicuous. If the Romans discovered that Joseph had retrieved Jesus before he was dead, and had conducted a decoy burial, Joseph would pay with his life. He would have had every reason to make it look to the Romans and Jewish hierarchy as if Jesus really had died on the cross and been buried in the tomb. The lower classes in first century Palestine were buried in simple shallow graves or shafts, without inscriptions or valuables (Crossan and Reed 2001, p. 245). There are some references to a less than honorable burial of Jesus (Kirby 2005, p. 246), which could recall an original rumor of Jesus' secret burial in a pauper's grave, or perhaps in a criminal graveyard (Carrier 2005a, pp. 380-384, 386). If this anonymous grave became the final resting place of Jesus, it may have been uncovered in subsequent years, but with no inscription, no one would know.

Jesus' brief survival would not easily have been kept a secret. One way or another, the rumor would have reached the disciples and the Roman authorities. The natural reaction to this stir would have been for the Romans to unseal the tomb, (perhaps three days after the crucifixion?) and of course, they would have found it empty except for a bundle of burial linen. They immediately would have come looking for Joseph. The followers of Jesus also would have heard the report of the empty tomb, and perhaps in some way, involving women, as per the Gospels, they confirmed it for themselves. The Jewish hierarchy also must have heard about the empty tomb, and they are reported to have accused Jesus' followers of stealing the body (Matthew 28:11-15). Joseph of Arimathea also would have heard the news, and that the Romans were coming for him. He would have had every incentive to leave town in a hurry and disappear, perhaps aided by some bribes. Perhaps Joseph was captured by the Romans. In the latter case, they may have disposed of him quietly, to avoid embarrassment and the attention of higher authorities. Joseph of Arimathea appears only in the Gospels, and is not mentioned in any other New Testament writing. Pilate may have had the tomb cleaned and promptly re-used, or defiled, or destroyed, in order to forestall any veneration of the site.

Could the followers of Jesus eventually have learned of his true resting place? Joseph of Arimathea would have had no incentive to mark the true grave of Jesus or identify the body in any way. If Joseph was killed by the Romans, the secret died with him. The handful of slaves who participated in the burial would have had every reason to keep quiet, or perhaps they were killed with him. If Joseph was able to flee, he very reasonably would have decided to avoid any contact with the disciples, in order to hide his whereabouts from the Romans. Survival would be more assured if Joseph and his slaves kept quiet and hidden. 


\section{Appearances}

The second key evidential claim by apologists is the reported appearances of Jesus to his followers after his crucifixion and death. Apologists readily admit they vary in number and detail, but liken this to the phenomenon of witnesses' varying accounts of a confirmed natural event. However, extending this to a confirmation of a man (the Son of God, no less) rising from the dead is not supportable on the available evidence. There is no contemporary account of Jesus, much less his appearance after death, from Roman, Jewish or other historians (Price 2003). Even though the reported appearances are not consistent between Gospels, (and absent from the original version of Mark), a resurrection belief was held by disciples from the earliest days (Aslan 2013, pp. 174-175). It is reasonable to conclude that they describe followers' memories of visions of a post-crucifixion Jesus.

The key detail in Gospel reports of a risen Jesus is that many include initial misidentifications. This is odd on the face of it. Jesus' devoted followers not recognizing their lord and master? But it makes perfect sense if the disciples reported visions or impressions of the voice and likeness of Jesus in others, which later became interpreted as a physical resurrection. Gospel reports of misidentifications are significant, in that they are not likely to be later insertions, because they could be read to cast doubt on the claim of a bodily risen Jesus. People of the first century commonly believed in possession by demons or spirits, visitations by gods, and the transmigration of souls, and the Old and New Testaments are full of references to such things (Smith 1978; Carrier 2005c, p. 184; Price 2011, pp. 229-230), and Jesus predicted his own resurrection on eleven different occasions (McCormick 2011, pp. 205-206), so it would not be surprising if reports of feeling the presence of a post-crucifixion Jesus in another person were readily accepted by disciples.

In Luke 24:15-32 a resurrected Jesus walks, talks, and eats with disciples but they don't recognize him. "But their eyes were holden that they should not know him". One of their number speaks to the unrecognized Jesus as a stranger; "...Art thou only a stranger in Jerusalem..?" (Luke 24:18). The disciples walk with an unrecognized Jesus, and prevail upon him to eat and spend the evening with them, all the while being harangued by Jesus for not believing! (Luke 24:25-30) In Luke 24:31 they recognize the stranger as Jesus, even as he vanishes from their sight. Finally, Luke 24:32 describes the apostles reminding themselves of how their hearts burned while the stranger talked to them. The apologist argument on these passages is that the disciples were temporarily blinded to test their faith, but it seems far more likely that they didn't initially recognize the stranger as Jesus because it wasn't Jesus. This episode in Luke is plausibly explained as a memory of seeing and feeling the presence of Jesus in others soon after the crucifixion. Modern studies clearly document how intense grief can result in the hallucination of a loved one, and mass hallucinations are a well-documented phenomenon (Parsons 2005, pp. 436-437, 442).

There are several other examples in the Gospels. Luke 24:36-37 "And as they thus spake, Jesus himself stood in the midst of them, and saith unto them, Peace be unto you. 
But they were terrified and affrighted, and supposed that they had seen a spirit." John 20:14-16 "And when she (Mary Magdalene) had thus said, she turned herself back, and saw Jesus standing, and knew not that it was Jesus. Jesus saith unto her, Woman, why weepest thou? whom seekest thou? She, supposing him to be the gardener, saith unto him, Sir, if thou have borne him hence, tell me where thou hast laid him, and I will take him away." It is hard to imagine such a close follower of Jesus as Mary Magdalene not recognizing him, much less thinking him the gardener. No suggestion is made that Jesus was in disguise. Mary Magdalene thought it was the gardener because, probably, it was the gardener, and she came to feel, in her distressed state, that there was something of her master in the person before her.

Again, in John 21:4 "But when the morning was now come, Jesus stood on the shore: but the disciples knew not that it was Jesus." Mark 16:9-12 (although perhaps a later addition, Kirby 2005) "Now when Jesus was risen early the first day of the week, he appeared first to Mary Magdalene, out of whom he had cast seven devils. And she went and told them that had been with him, as they mourned and wept. And they, when they had heard that he was alive, and had been seen of her, believed not. After that he appeared in another form unto two of them, as they walked into the country."

The Gospels and 1 Corinthians 15:5-8 report several appearances of a post-crucifixion Jesus to his followers. The Gospels depict Jesus as resurrected in the body that was buried, but Paul in 1 Corinthians 15:44-54 implies that the risen Jesus left his old body behind and appeared in a glorious new body. Notably, the words Paul uses are neutral with respect to either version (Parsons 2005, p. 434; Wedderburn 1999, pp. 66-91, 118-120). This contradiction can be reconciled by concluding that the first Christians, including Paul, thought Jesus was resurrected in a new body, and that the appearances were visions and dreams. The belief in a physical resurrection of the body that was buried, and appearances in the flesh, as reported in the Gospels, evolved later (Carrier 2005c, pp. 105-106, 188; Parsons 2005, p. 434). If modern believers can see an image of Jesus in a piece of toast, it isn't hard to imagine that the first disciples believed they felt the person of their master in other people. Paul says little about the crucifixion of Jesus, perhaps because the Roman world thought it abominable to worship a crucified god, and this was a major impediment to proselytization (Hengel 1977, pp. 15-19, 61-62, 83). Some Bible scholars point to this difference in the nature of a risen Jesus as supporting a view that he was just a composite of mythical figures, not a real person (Fitzgerald 2010, pp. 125-132). But it is also plausible that the earliest church writings reflect a more accurate account of the disciples' first memories, and that crucifixion details were downplayed in early accounts to make the new religion more attractive to gentiles.

\section{Conclusion}

Clues in the Gospels, evidence from the Jewish historian Josephus, belief in the transmigration of souls, and well-documented examples of erroneous declarations of death, combine to support a natural explanation for the resurrection and appearance stories on which Christian faith rests: (1) Jesus survives his short stay on the cross, and (2) is discovered to be barely alive by the few followers who retrieve him. (3) 
Fearful because they have illegally retrieved a condemned man, they carry out a decoy burial in a tomb. (4) Jesus expires soon after, and is buried quietly in an anonymous grave, but (5) rumor of his survival reaches his followers, as well as the Romans, who (6) open the tomb and find it empty, except for burial linen used in the decoy. (7) The high status Jew who recovered the (barely alive) Jesus from the cross leaves town in a hurry when the Romans come looking for him. (8) To sooth their grief the disciples seize on the rumor of Jesus' survival and encourage each other to hear the voice and see the image of their master in others, and (9) inspired by what they believe is a miraculous resurrection, slowly build a following.

Christianity accepts a supernatural interpretation of the empty tomb and appearance stories, but compared to other historical claims of the supernatural, the evidence is extremely thin. A voluminous record of the 1692 Salem witch trials is preserved in original court transcripts, depositions, diaries, and letters, yet despite this excellent record from the relatively recent past, few modern people think there was an epidemic of witchcraft. Instead it only required a confluence of natural events and superstition to bring about the execution of 20 people, and two dogs, on charges of witchcraft (McCormick 2011, pp. 207-216; http://law2.umkc.edu/ faculty/projects/ftrials/salem/SAL_ACCT.HTM). Further, if one believes witchcraft was afoot in Salem, then one also should accept that Joseph Smith really recovered divine golden plates, because Mormons have statements from eleven contemporaries testifying to their existence (Fitzgerald 2013, p. 41-44). In these, and many more cases, the overwhelming majority of observers accept a natural explanation for claimed supernatural events. The resurrection and appearance stories about Jesus should be seen the same way.

Although the probability of the chain of events proposed in this paper is low, it is surely far larger than the supernatural model. It also is arguably more likely than other non-supernatural hypotheses. It does not require Jesus to survive his crucifixion and meet his followers (Joyce 1972), or to have his body stolen (Carrier 2005 b), or be removed from the tomb after the Sabbath and reburied in a pauper or criminal graveyard (Lowder 2005, pp. 271, 295-297; Carrier 2005a, p. 369). One only need propose that Jesus was still alive (barely) when recovered and envision how events most likely would unfold from there.

Open Access This article is distributed under the terms of the Creative Commons Attribution 4.0 International License (http://creativecommons.org/licenses/by/4.0/), which permits unrestricted use, distribution, and reproduction in any medium, provided you give appropriate credit to the original author(s) and the source, provide a link to the Creative Commons license, and indicate if changes were made.

\section{References}

Aslan, R. (2013). Zealot, the life and times of Jesus of Nazareth. New York, NY: Random House.

Bondeson, J. (2001). Buried alive: The terrifying history of our most primal fear. New York: W. W. Norton \& Company.

Carrier, R. C. (2005a). The burial of Jesus in light of jewish Law. In R. M. Price \& J. J. Lowder (Eds.), The empty tomb (pp. 369-392). Amherst, NY: Prometheus Books.

Carrier, R. C. (2005b). The plausibility of theft. In R. M. Price \& J. J. Lowder (Eds.), The empty tomb (pp. 349-368). Amherst, NY: Prometheus Books. 
Carrier, R. C. (2005c). The spiritual body of christ and the legend of the empty Tomb. In R. M. Price \& J. J. Lowder (Eds.), The empty tomb (pp. 105-231). Amherst, NY: Prometheus Books.

Craig, W. L. (1994). Reasonable faith: Christian truth and apologetics. Wheaton, IL: Crossway Books.

Craig, W. L. (2010). On guard: Defending your faith with reason and precision. Colorado Springs, CO: David C. Cook, Publisher.

Crossan, J. D., \& Reed, J. L. (2001). Excavating Jesus: Beneath the stones, behind the texts-the key discoveries for understanding Jesus in his world. New York, NY: HarperCollins.

Davies, R. (1998). The Lazarus syndrome: Burial alive and other horrors of the undead. New York, NY: Barnes and Noble Books.

Derrett, J., \& Duncan, M. (2005). Financial aspects of the resurrection. In R. M. Price \& J. J. Lowder (Eds.), The empty tomb (pp. 393-409). Amherst, NY: Prometheus Books.

Fitzgerald, D. (2010). Nailed ten christian myths that show Jesus never existed at all. Lulu Press, Inc. https://www.lulu.com.

Fitzgerald, D. (2013). The complete heretic's guide to Western Religion: The Mormons. Self-published by David Fitzgerald www.davefitzgerald.blogspot.com.

Habermas, G., \& Licona, M. (2004). The case for the resurrection of Jesus. Grand Rapids, MI: Kregel Publications.

Hengel, M. (1977). Crucifixion. Philadelphia: Fortress Press.

Josephus, F. (1900). The life of Flavius Josephus. In The Complete Works of Flavius-Josephus The Celebrated Jewish Historian (W. Whiston, Trans.). Chicago: Thompson and Thomas, pp 25-26 $\left(1^{\text {st }}\right.$ Century CE)

Josephus, F. (1981). The Jewish war. (G. A. Williamson, Trans. \& revised by E. M. Smallwood). London: Penguin Books (1st Century CE)

Joyce, D. (1972). The Jesus Scroll. New York, NY: New American Library.

Kirby, P. (2005). The case against the empty tomb. In R. M. Price \& J. J. Lowder (Eds.), The empty tomb (pp. 233-260). Amherst, NY: Prometheus Books.

Kirsch, J. (2004). God against the Gods. The history of the war between monotheism and polytheism. New York, NY: Penguin Compass.

Komarnitsky, K. (2013). Myth growth rates, a close look at the linchpin of Lee Strobel's case for christ. Free Inquiry, 33(2), 37-41.

Kraemer, R. S. (2004). Women's religions in the Greco-Roman world: A sourcebook. New York, NY: Oxford University Press.

Lowder, J. J. (2005). Evidence and the empty tomb story: A reply to William Lane Craig. In R. M. Price \& J. J. Lowder (Eds.), The empty tomb (pp. 261-306). Amherst, NY: Prometheus Books.

McCormick, M. (2011). The Salem Witch trials and the evidence for the resurrection. In J. W. Loftus (Ed.), The empty tomb (pp. 195-217). Amherst, NY: Prometheus Books.

Moss, C. (2013). The myth of persecution: How early christianity invented a story of Martyrdom. New York, NY: HarperCollins.

O'Grady, S. (2012). And man created God: A history of the World at the Time of Jesus. New York, NY: St. Martin's Press.

Parsons, K. (2005). Peter Kreeft and Ronald Tacelli on the Hallucination theory. In R. M. Price \& J. J. Lowder (Eds.), The empty tomb (pp. 433-451). Amherst, NY: Prometheus Books.

Price, R. M. (2003). The incredible shrinking son of man-how reliable is the gospel tradition? Amherst, NY: Prometheus Books.

Price, R. M. (2011). Explaining the resurrection without recourse to miracle. In J. W. Loftus (Ed.), The end of christianity (pp. 219-232). Amherst, NY: Prometheus Books.

Schonfield, H. (1965). The passover plot-a new interpretation of the life and death of Jesus. Rockport, MA: Element Publishing.

Smith, M. (1978). Jesus the magician. New York, NY: Harper and Row.

Strobel, L. (1998). The case for christ-a journalist's personal investigation of the evidence for Jesus. Grand Rapids, MI: Zondervan Publishing House.

Thiering, B. (1992). Jesus and the riddle of the dead sea scrolls: Unlocking the secrets of his life story. San Francisco, CA: HarperCollins.

Wedderburn, A. J. M. (1999). Beyond resurrection. Peabody, MA: Hendrickson Publishers.

Wilkins, R. (1990). Death: A history of man's obsessions and fears. New York, NY: Barnes and Noble Books.

Zugibe, F. T. (1984). Death by crucifixion. Canadian Society of Forensic Science Journal, 17, 1-13. 